\title{
Lower back pain caused by tophaceous gout of the spine
}

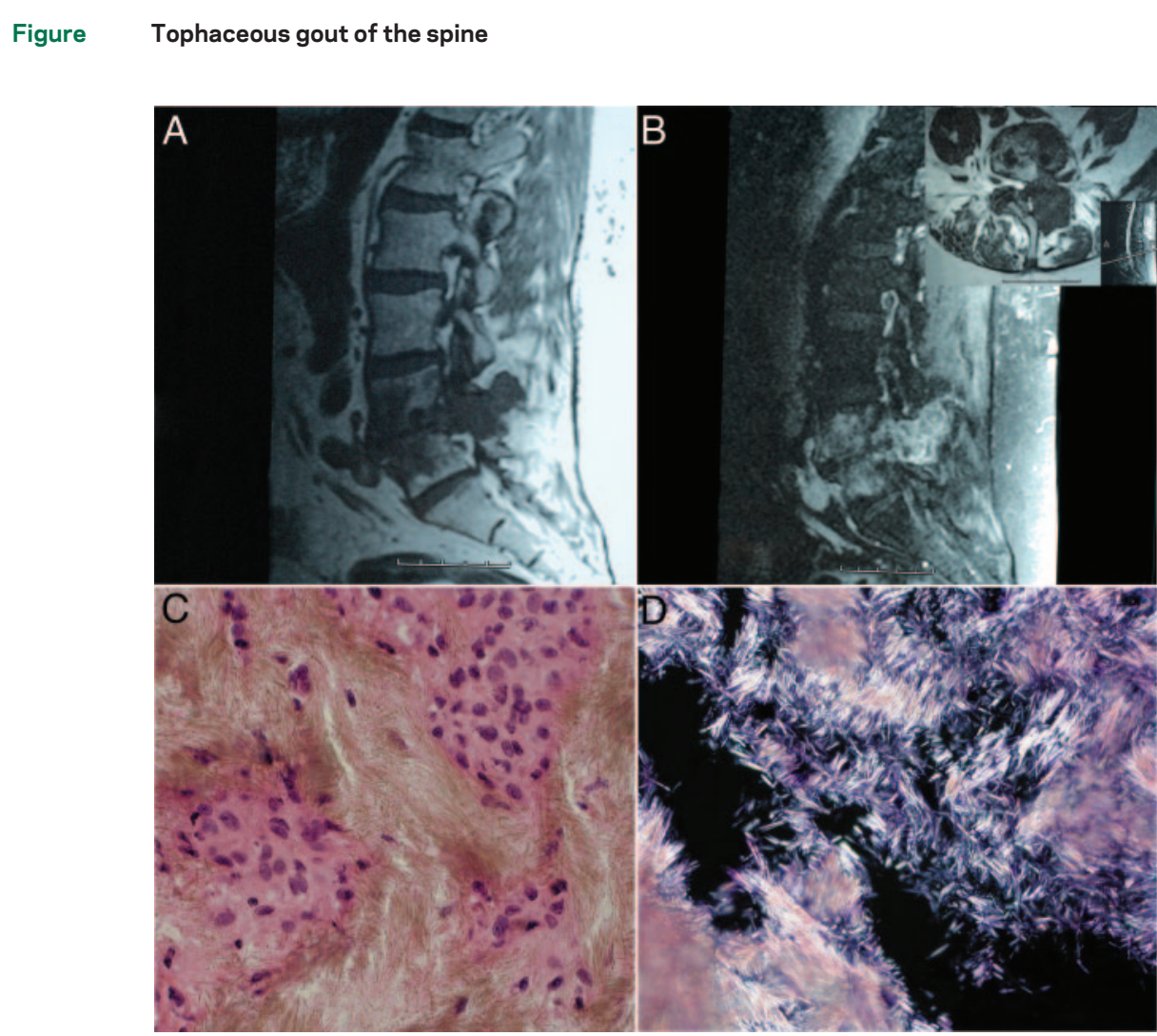

MRI shows abnormal signal intensity at L4-5 on T1-weighted sequences ( $A$ and $B$ inset), with corresponding contrast enhancement (B). Analyses of biopsy were consistent with tophaceous gout. Hematoxylin-eosin stain shows brown aggregates of urate crystals surrounded by an inflammatory reaction (C), and polarizing microscopy reveals typical birefringent crystals (D).

A 75-year-old man with a history of gout presented with 5 days of fever and diffuse lower back pain. His temperature was $101.5^{\circ} \mathrm{F}$, and he had tenderness over both thoracic and lumbar vertebrae. His neurologic examination was largely normal. Erythrocyte sedimentation rate was $100 \mathrm{~mm} / \mathrm{h}$, and serum uric acid $18.6 \mathrm{mg} / \mathrm{dL}$. Subsequent workup, including MRI and biopsy (figure), was consistent with tophaceous gout of the spine. Spinal gout is rarely reported, and can be mistaken for a spinal epidural abscess. ${ }^{1} \mathrm{~A}$ recent study suggests the frequency of axial involvement may be as high as $14 \%$ in patients with clinical or crystal-proven gout. ${ }^{2}$

Haakon B. Nygaard, MD, Sheela Shenoi, MD, and Salil Shukla, MD, New Haven, CT

Disclosure: Dr. Shenoi has received research support from the NIH 5 T32 AI007517) through Yale University, and is currently supported by the Fogarty International Clinical Fellowship (FICRF) (\#R24TW007988). Her spouse, Ralph Brooks, was employed by and holds stock option in Merck \& Company.

Address correspondence and reprint requests to Dr. Haakon B. Nygaard, Department of Neurology, Cellular Neuroscience, Neurodegeneration and Repair Program (CNNR), Yale University School of Medicine, 295 Congress Ave., BCMM 436, New Haven, CT 06536-0812; haakon.nygaard@yale.edu

1. Barrett K, Miller ML, Wilson JT. Tophaceous gout of the spine mimicking epidural infection: case report and review of the literature. Neurosurgery 2001;48:1170-1172.

2. Konatalapalli RM, Demarco PJ, Jelinek JS, et al. Gout in the axial skeleton. J Rheumatol 2009;36:609-613. 


\section{Neurology}

\section{Lower back pain caused by tophaceous gout of the spine \\ Haakon B. Nygaard, Sheela Shenoi and Salil Shukla}

Neurology 2009;73;404

DOI 10.1212/WNL.0b013e3181b04cb1

This information is current as of August 3, 2009

Updated Information \&

Services

References

Permissions \& Licensing

Reprints including high resolution figures, can be found at:

http://n.neurology.org/content/73/5/404.full

This article cites 2 articles, 1 of which you can access for free at: http://n.neurology.org/content/73/5/404.full\#ref-list-1

Information about reproducing this article in parts (figures,tables) or in its entirety can be found online at:

http://www.neurology.org/about/about_the_journal\#permissions

Information about ordering reprints can be found online:

http://n.neurology.org/subscribers/advertise

Neurology ${ }^{\circledR}$ is the official journal of the American Academy of Neurology. Published continuously since 1951, it is now a weekly with 48 issues per year. Copyright. All rights reserved. Print ISSN: 0028-3878. Online ISSN: 1526-632X.

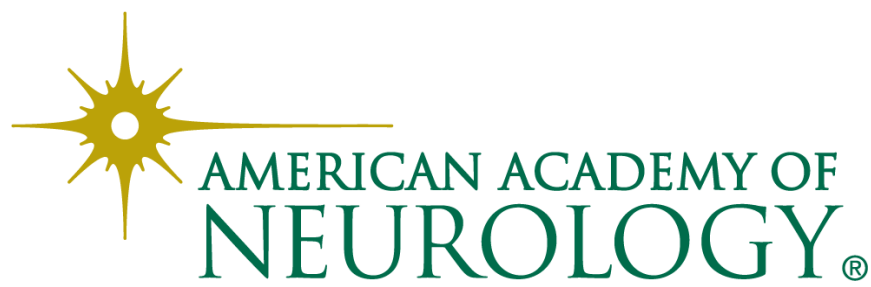

